Italy

\title{
New hope for research council
}

SCIENTIFIC hearts are beating faster in Italy this week, as real hopes emerge of genuine reform of Italy's major but chaotic research council, the Consiglio Nazionale delle Ricerche (CNR). Last week the Italian Parliament ended eight years of colourful Neapolitan presidency of CNR by appointing a dynamic Milanese enzymologist, Professor Luigi Rossi Bernardi, to the next four-year presidential term. With Rossi Bernardi at the helm, the control of CNR passes from the underdeveloped south of Italy to the better-organized and industrial north: certainly the most fundamental event in Italian science politics for some time.

However, Rossi Bernardi is fully aware of the magnitude of his task. "Don't promise too much", he warned last week. Rossi Bernardi knows CNR from inside as a past president of the CNR medicine and biology committee. He identifies the key issue as that of quality: the proper allocation of resources, posts and promotions on the basis of scientific merit rather than custom or seniority. This means confronting interests, inevitably a political job. But Rossi Bernardi has powerful political friends, in the socialist prime minister Bettino Craxi, in the Christian Democrat research minister Luigi Granelli (both Milanese) and in the Christian Democrat party itself (which nominated him). He belongs to no political party, and says he will manage CNR "as a scientist", with the sole objective of improving the quality of CNR-supported science; but it will certainly be no hindrance to him to have friends in the right places. It will help also, said a colleague, that he comes from a medical department, medics being "the strongest mafia - in the best sense - in the Italian universities".

Rossi Bernardi is regarded as a proven organizer, both in his earlier work at CNR and his department in Milan. He is not greatly concerned, he says, with the total budget of CNR - which will grow 10 per cent next year, roughly in line with inflation. "The real problem is how the money is spent", he says.

Rossi Bernardi must also cut through the usual trip-wires with which Italian administration likes to entangle itself, such as a law recently passed which allows CNR institutes (and other state organizations) to hold as fluid funds only four per cent of their annual budgets, the rest remaining in the state treasury. The rule was originally designed to stop misappropriation, but its effect has been catastrophic, as CNR institutes are now having to request additional funds almost weekly from Rome. "We are at a standstill all over Italy", says one Naples biologist.

Another problem facing Rossi Bernardi is the fact that something like half of all CNR scientists have published nothing for five years (according to a survey he instituted two years ago). And the council languishes under a law which treats scien- tists as the most routine kind of civil servant, inhibiting promotion on merit (substituting seniority) and all but forbidding appointments into CNR at high level (as laboratory directors, for example). "It's a very, very hard job"', says Rossi Bernardi.

Robert Walgate

\section{Expelled think-tank finds Rand}

Army research

\section{Los Angeles}

THE US Army's new think-tank, given the cold shoulder by faculty of the California Institute of Technology earlier this year, has at last found a home. Within the next few months, the Arroyo Center will move from its present quarters at the Jet Propulsion Laboratory (JPL, administered by Caltech) to the Rand Corporation, located in another part of greater Los Angeles.

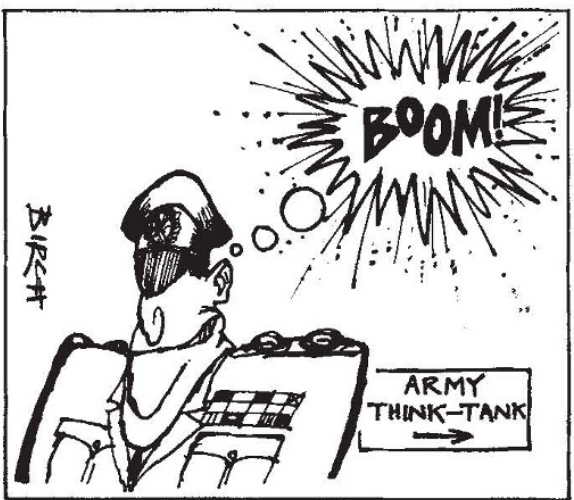

Rand has been home to the US Air Force's think-tank since the Second World War. "We don't see that there's a conflict"', said Donald Rice, Rand's president and chief executive officer, who said that "for decades" Rand has been working for both the Air Force and the office of the
Secretary of Defense as well as several other components of the Department of Defense, the Army and the Navy included.

Both the Navy and the Air Force have independent think-tanks, and the Army two years ago decided that it also needed one. The centre's charter is to examine long-term issues involving defence strategies, military operations, resource management and advanced technology as they affect the future Army.

As the centre began to set up shop last spring under Caltech's wing, the faculty balked. A majority said it was inappropriate for the university to lend its name and reputation to an organization that would lobby on behalf of military interests. Although it was acknowledged that many faculty members work on defence matters, it was argued that the university as a whole should not.

Caltech president, Marvin Goldberger, was criticized, but quickly forgiven, for having let the arrangement take place without prior faculty approval. The centre was moved to the nearby JPL campus and asked to look for another home.

At Rand, the Arroya Center will become a fifth division joining Project Air Force and other national security research, domestic research and the Institute for Civil Justice.
Sandra Blakeslee

\section{Nature index of biotechnology stocks}

\begin{tabular}{|c|c|c|c|c|c|}
\hline $\begin{array}{l}\text { 12-Month } \\
\text { high }\end{array}$ & $\begin{array}{l}\text { 12-Month } \\
\text { low }\end{array}$ & Company & $\begin{array}{l}\text { Close } \\
\text { previous } \\
\text { month }\end{array}$ & $\begin{array}{l}\text { Close } \\
28 \text { September }\end{array}$ & Change \\
\hline 14 & 6 & Biogen (Switzerland) & 8 & 8 & $\mathbf{0}$ \\
\hline 2 & 1 & Bio-Logicals (Canada) & $11 / 4$ & $11 / 4$ & $\mathbf{0}$ \\
\hline $14 \frac{3}{8}$ & $61 / 2$ & Bio-Response (USA) & $91 / 2$ & $73 / 4$ & $-13 / 4$ \\
\hline $14^{1 / 8}$ & $91 / 4$ & Cetus (USA) & $11^{3 / 8}$ & 11 & $-3 / 8$ \\
\hline $103 / 8$ & $41 / 4$ & Collaborative Research (USA) & $61 / 4$ & $55 / 8$ & $-5 / 8$ \\
\hline $19 \%$ & $11 \frac{1}{2}$ & Damon (USA) & $141 / 2$ & $14 \frac{5}{8}$ & $+1 / 8$ \\
\hline $261 / 4$ & $113 / 4$ & Enzo-Biochem (USA) & $141 / 4$ & $141 / 2$ & $+1 / 4$ \\
\hline $10 \frac{1}{8}$ & $41 / 4$ & Flow General (USA) & $53 / 8$ & $51 / 4$ & $-1 / 8$ \\
\hline $421 / 4$ & $283 / 8$ & Genentech (USA) & $331 / 4$ & $303 / 4$ & $-21 / 2$ \\
\hline $103 / 4$ & $41 / 2$ & Genetic Systems (USA) & $67 / 8$ & $63 / 4$ & $-1 / 8$ \\
\hline $171 / 4$ & $81 / 4$ & Genex (USA) & 12 & $93 / 4$ & $-21 / 4$ \\
\hline 23 & 11 & Hybritech (USA) & $141 / 4$ & $131 / 4$ & -1 \\
\hline $161 / 4$ & $71 / 4$ & Molecular Genetics (USA) & $101 / 4$ & $73 / 4$ & $-21 / 2$ \\
\hline $151 / 2$ & $81 / 4$ & Monoclonal Antibodies (USA) & 10 & $103 / 4$ & $+3 / 4$ \\
\hline $607 / 8$ & $32 \frac{1}{8}$ & Novo Industri A/S (Denmark) & $371 / 4$ & $33 \frac{3}{8}$ & $-37 / 8$ \\
\hline $223 / 4$ & $141 / 2$ & Pharmacia (Sweden) & 19 & $17 \%$ & $+1 \frac{1}{8}$ \\
\hline
\end{tabular}

Closing prices are for the last Friday of the month. For over-the-counter stocks, bid price is quoted; for stocks on the American and New York exchanges, the transaction price. Nature's weighted index of biotechnology stocks stood at 139 on 28 September, compared with 149 a month earlier. Data from E.F. Hutton, Inc. 